ORIGINAL PROF-2019

\title{
DIABETES MELLITUS;
}

\author{
Incidence of chronic hepatitis c patients
}

Dr. Ghazanfar Ali Sindhu, Dr. Sadaf Naz, Dr. Fraz Saeed Qureshi, Dr. Zaheer Ahmed, Dr. Tamur Islam

ABSTRACT... Introduction: Hepatitis C virus (HCV) is a major cause of chronic liver disease, cirrhosis and hepatocellular carcinoma (HCC). HCV infection and type 2 diabetes are two common disorders with a high impact on health worldwide. There is growing evidence to support the concept that HCV infection is a risk factor for developing type 2 Diabetes Mellitus. Both insulin resistance and diabetes can adversely affect the course of chronic hepatitis C, and lead to poor response to antiviral therapy and increased incidence of Hepatocellular carcinoma. Objective: The objective of the study was to assess the frequency of type 2 Diabetes mellitus in newly diagnosed chronic hepatitis C patients presenting in Allied hospital Medical unit II during six month period. Design: Cross sectional study. Setting: Medical unit-II, Allied Hospital, Faisalabad. Period: 01-08-2009 to 28-02-2010. Material and methods: All newly diagnosed patients of chronic hepatitis $C$ on the basis of PCR for HCV-RNA were included in the study. Fasting and two hours postprandial blood sample were tested. Diabetes Mellitus was labeled as per slandered. Results: Out of 180 patients with CHC 19 (10.6\%) were found to have Diabetes mellitus while 161(89.4\%) were non-diabetics. Conclusions: There is close association in the development of type 2 diabetes mellitus in patients with chronic hepatitis C.

Key words: Chronic hepatitis C, Type 2 Diabetes mellitus, insulin resistance.

Article Citation

Sindhu GA, Naz S, Qureshi FS, Ahmed Z, Islam T. Diabetes mellitus; Incidence of chronic hepatitis C patients. Professional Med J 2013;20(2): 220-226.

\section{INTRODUCTION}

Hepatitis B and C are global health care problems causing morbidity and mortality worldwide and spreading like an epidemic in developing countries like Pakistan, especially in rural areas ${ }^{1,2,3}$. WHO estimated 1- 3\% worldwide prevalence of HCV, and 3-4 million new cases arising each year ${ }^{4}$.

Blood and blood products transfusion and infected needles are two preventable modalities of spread of hepatitis C infection while sexual transmission remains controversial ${ }^{5,6}$.

HCV is the cause of approximately $20 \%$ of cases of acute hepatitis, most often asymptomatic and rarely causes hepatic failure. The majority, up to $85 \%$ enter a chronic phase and out of these $20 \%$ will progress to cirrhosis and its complications after 20 years ${ }^{7,8,9,10,11,13}$.

Chronic hepatitis C virus infection is present in $3-10 \%$ of Pakistani population and genotype 3 is the most prevalent subtype ${ }^{12}$. The rate of spontaneous clearance of virus after it has persisted for at least six months is very low ${ }^{9}$.

Cirrhosis along with its complications like encephalopathy, ascites and portal hypertensive bleeding, is the $12^{\text {th }}$ most common cause of death and the most common cause of non-malignancy related death among patients with diseases of the digestive $\operatorname{tract}^{14,15,16,17,18,19}$.

Type 2 diabetes (T2D) and HCV infection are common conditions involving at least 170 and 130 million people respectively worldwide ${ }^{20}$.

Like other complications of chronic hepatitis C including cirrhosis of liver and Hepatocellular carcinoma, there is growing evidence suggesting mutual link between chronic hepatitis $C$ and increased risk of developing type 2 Diabetes mellitus and glucose abnormalities ${ }^{21,22}$.

The risk factors associated with development of type 2 
Diabetes mellitus in general population alone cannot account for the high prevalence of type 2 Diabetes mellitus in patients with chronic hepatitis $\mathrm{C}^{23}$. Increased insulin resistance (IR) seems to be a specific feature of chronic hepatitis $\mathrm{C}^{24}$. In chronic hepatitis $\mathrm{C}$, insulin resistance and type 2 diabetes mellitus are more often seen than in healthy controls or chronic hepatitis B patients ${ }^{25,26}$. Inflammatory cytokines, including TNF- $\alpha$ are an integral part of inflammation in chronic hepatitis $C$ infection. It has recently been suggested that chronic sub-clinical inflammation is associated with insulin resistance, and precedes the development of type $2 \mathrm{DM}^{26}$.

In summary, hepatitis $\mathrm{C}$ promotes insulin resistance and insulin resistance induces interferon resistance, steatosis and fibrosis progression ${ }^{27}$. Development of glucose abnormalities and type 2 Diabetes mellitus may lead to poor response to anti viral therapy and increased incidence of Hepatocellular carcinoma ${ }^{28}$. T2D and IR are independent predictors of a more rapid progression of liver fibrosis and impaired response to antiviral treatment in chronic hepatitis $\mathrm{C}^{29}$.

Diagnosing and treating insulin resistance in patients with chronic hepatitis C could not only avoid complications but also prevent disease progression and increased the sustained virological rate to treatment with pegylated interferon plus ribavarin ${ }^{30}$.

\section{Objective}

To determine the frequency of type 2 Diabetes mellitus in newly diagnosed patients of chronic hepatitis in Faisalabad.

\section{Operational definition}

Fasting blood sugar level $>110 \mathrm{mg} / \mathrm{dl}$ or $>200 \mathrm{mg} / \mathrm{dl}$ two hours after meal were labeled as having diabetes mellitus.

Patients both positive with Anti-HCV antibodies by ELISA and PCR for at least six months were labeled as having chronic Hepatitis $\mathrm{C}$ disease.

\section{MATERIAL AND METHOD}

Study design

Cross sectional study

Study Setting

Medical unit II Allied Hospital Faisalabad.

\section{Duration of study}

Six months, from 01.08.2009 to 28.02.2010

\section{Inclusion Criteria}

Age $>30$ years, All patients with more than six months history of hepatitis $C$ confirmed by enzyme linked immunosorbant assay (ELISA) and PCR for HCV- RNA qualitative test.

\section{Exclusion Criteria}

Patients with chronic hepatitis B, known diabetics or having family history of diabetes, HIV positive patients. Patients with clinical decompensated cirrhosis or cancer

\section{Data collection procedure}

All patients admitted in Allied hospital M unit II with hepatitis $C$ on the basis of $>6$ months history of hepatitis $C$ confirmed by enzyme linked immunosorbant assay (ELISA) and +ve PCR for HCV RNA. had been taken as having chronic hepatitis $C$. Informed written consent taken from patients after explaining procedure in detail. Fasting blood sugar level was taken early in the morning in sterilized syringes under aseptic measures. Random blood sugar was taken two hours after meals in sterilized syringes and sent for FBS RBS, SGPT and billirubin. Data of all patients was collected through Proforma.

\section{RESULTS}

In this study total 180 patients having chronic hepatitis C were included. Minimum age of the pt. was 34 and maximum 70 with a mean and STD of 53.40 and8.64 


\begin{tabular}{|l|c|c|c|c|c|}
\hline & N & Minimum & Maximum & Mean & Std. Deviation \\
\hline Age of the patients & 180 & 34 & 70 & 53.40 & 8.64 \\
\hline Fasting blood glucose level & 180 & 67 & 141 & 91.48 & 14.00 \\
\hline Random blood glucose level & 180 & 123 & 310 & 161.29 & 35.10 \\
\hline Billirubin & 180 & .80 & 2.20 & 1.0906 & .2150 \\
\hline SGPT of patients & 180 & 22 & 56 & 33.53 & 5.18 \\
\hline Valid N (list wise) & 180 & & & & \\
& \multicolumn{2}{|l|}{ Table-I. Descriptive statistical analysis } & &
\end{tabular}

\begin{tabular}{|c|c|c|c|c|c|}
\hline & & Frequency & Percent & Valid percent & Cumulative percent \\
\hline \multirow{3}{*}{ Valid } & Female & 87 & $48.3 \%$ & $48.3 \%$ & $48.3 \%$ \\
\cline { 2 - 6 } & Male & 93 & $51.7 \%$ & $51.7 \%$ & $100.0 \%$ \\
\cline { 2 - 6 } & Total & 180 & 100.0 & 100.0 & \\
\hline
\end{tabular}

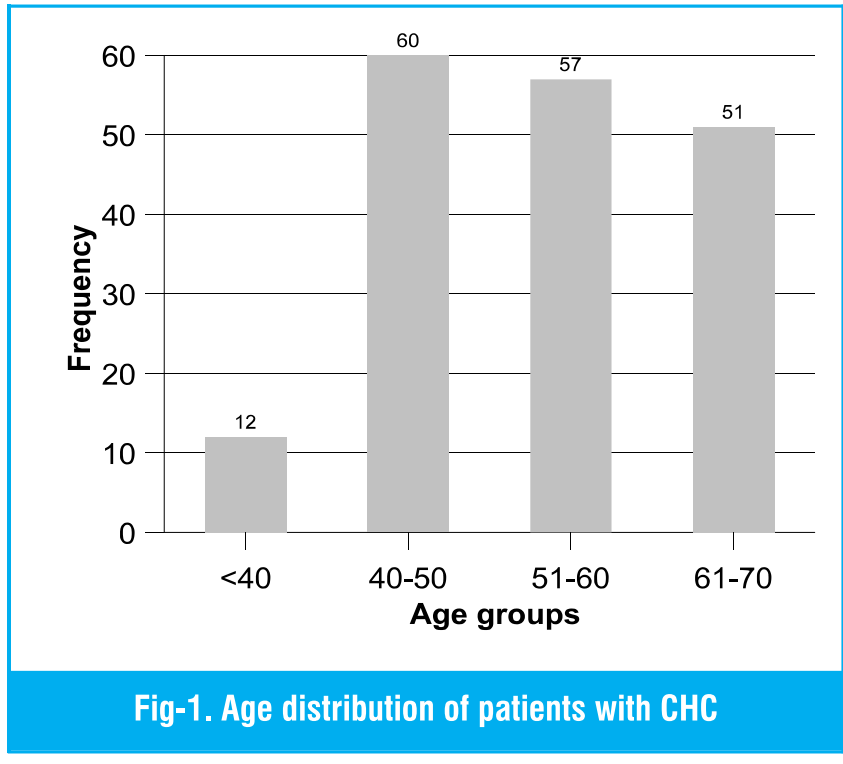

respectively (table I) Out of total 180 patients, 93 $(51.7 \%)$ were males and $87(48.3 \%)$ were females (table II).

Among age distribution the study showed that out of total 180 patients 12 (6.7\%) patients were having age

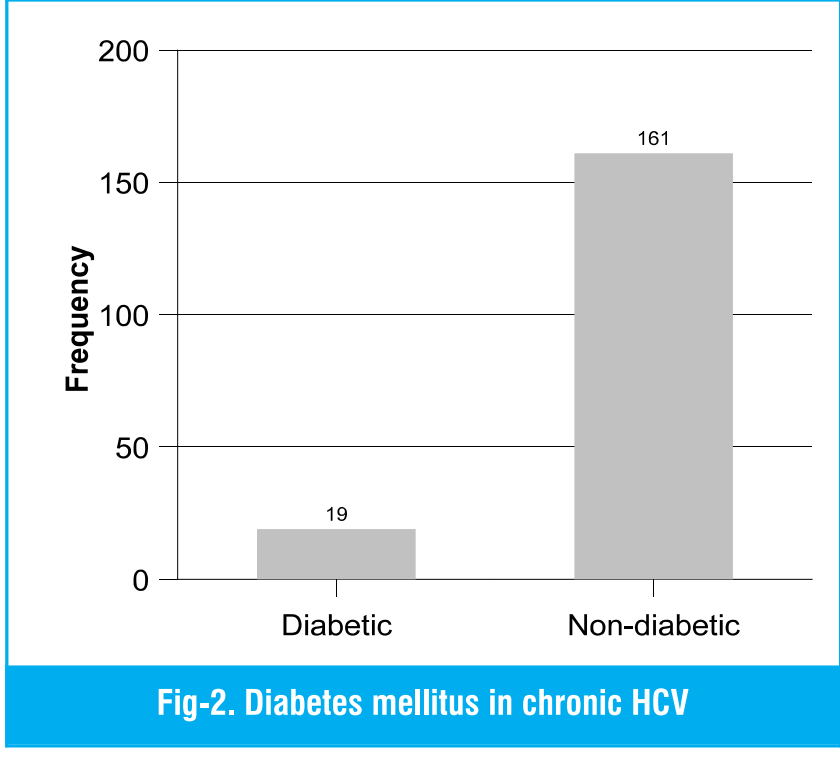

$<40$ years. Majority of them were among 40-70 years of age groups. Sixty (33.3\%) were having age from 4050 years and 57 patients (31.7\%) were having their ages between $51-60$ years and remaining 51 patients (28.3\%) were having ages between $61-70$ years (Fig$1)$. 


\begin{tabular}{|c|c|c|c|c|c|}
\hline & & Frequency & Percent & Valid percent & Cumulative percent \\
\hline \multirow{3}{*}{ Valid } & Diabetic & 19 & $10.6 \%$ & $10.6 \%$ & $10.6 \%$ \\
\cline { 2 - 6 } & Non diabetic & 161 & $89.4 \%$ & $89.4 \%$ & $100.0 \%$ \\
\cline { 2 - 6 } & Total & 180 & 100.0 & 100.0 & \\
\hline
\end{tabular}

Table-III. Association of chronic HCV with diabetes mellitus

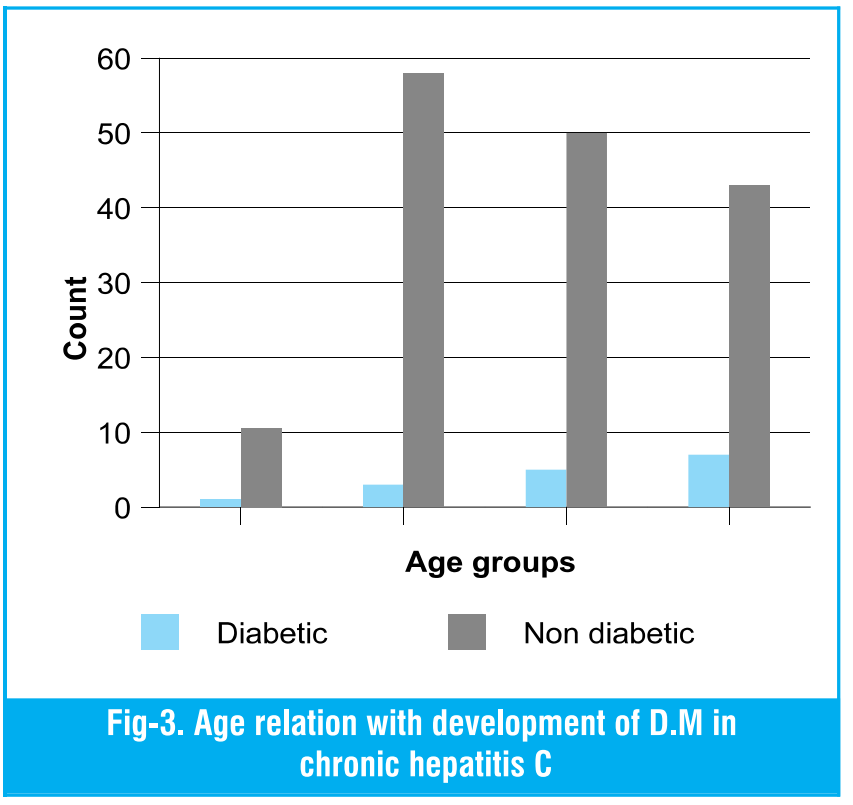

The study showed, out of 180 patients with Chronic hepatitis C 19 (10.6\%) were found to have Diabetes mellitus while $161(89.4 \%)$ were having no Diabetes mellitus on the basis of measured FBS,RBS levels falling in Diabetic range. (table III, Fig-2).

Out of 19 patients no one was having jaundice. Most patients presented with Diabetes Mellitus in pts. With $\mathrm{CHC}$ having age group 50-70.(Fig-3).

\section{DISCUSSION}

Hepatitis $\mathrm{C}$ and diabetes mellitus are global health care problems assuming epidemic. HCV infects approximately 170 million individuals worldwide and estimated to be responsible for approximately 250,000 to 350,000 deaths per year.

Chronic hepatitis C has recently been proposed as a metabolic disease and insulin sensitivity as a predictive factor for liver fibrosis. There is well established relation between cirrhosis of liver and development of diabetes mellitus as its extra hepatic complication, Thyroid disorders being the next common endocrine association. Diabetes developed as a complication of cirrhosis is known as hepatogenous diabetes (HD). Around $30 \%$ to $60 \%$ of cirrhotic patients suffer from this metabolic disorder ${ }^{31}$. Allison et al. ${ }^{32}$ reported that cirrhotic patients with HCV more frequently have T2D than cirrhosis with other etiology.

This study was conducted to determine the frequency of type 2 D.M in patients having chronic hepatitis C. Out of 180 patients, 19 (10.6\%) had Diabetes mellitus with somewhat male preponderance. Same was reported by Khokhar $\mathrm{N}^{33}$ from Islamabad.

Qureshi $\mathrm{F}$ et al ${ }^{34}$ reported threefold increase in the prevalence of D.M in the background of positive family history in chronic Hepatitis C. Claudia 0 Zein et a ${ }^{35}$ reported $14.5 \%$ incidence against $7.8 \%$ in American population.

Alavian SM, et al ${ }^{36}$ reported $18.3 \%$ prevalence of DM among HCV-infected patients from Iran. Suliman MI et a ${ }^{22}$ reported $19 \%$, against $8 \%$, incidence of DM in chronic hepatitis $\mathrm{C}$ patients in Bahawalpur.

Lecube et al, ${ }^{37}$ reported three fold increase in glucose metabolism abnormalities even in pre-cirrhotic stage in patients with chronic hepatitis $C$ independently of duration and stage of liver disease. Ryu JK et a ${ }^{38}$ 
reported similar results in Korean patients. All these studies stands fairly close to my results.

As cross-sectional nature of these studies cannot establish whether D.M or chronic HCV occurred earlier, longitudinal studies are needed. We excluded both known diabetic patients and even the patients with strong family history of DM to prove the point. The Atherosclerosis Risk in Communities Study, from America showed de novo development of T2DM over 9 years of follow-up in high risk patients as defined by family history and BMI. In a Taiwanese study ${ }^{39}$,over a follow-up of 7 years, $14.3 \%$ of anti-HCV-positive, $7.5 \%$ of $\mathrm{HBsAg}$-positive, and $8.6 \%$ of seronegative individuals developed T2DM.

The high co-incidence of HCV and IR/T2Dm cannot be assigned to chance, some protein component of the virus directly or indirectly through cytokines, like TNFa may be responsible. As abnormalities in glucose metabolism influences treatment outcome and disease progression, early detection and management of metabolic disorder is warranted.

Lifestyle modification and Insulin sensitizers are currently being evaluated in clinical trials.

Early screening of patients with chronic HCV infection for detection of diabetes and glucose metabolism disorders is recommended to improve patients' outcome and vice versa

\section{CONCLUSIONS}

HCV infection and type 2 diabetes are two common disorders with a high impact on health worldwide. The inference drawn from this study is that; a high frequency of type 2 Diabetes Mellitus among HCVinfected patients with chronic hepatitis has been observed, and supporting the concept that HCV infection is a risk factor for developing type 2 Diabetes.

Considering the disease burden and high economic cost of chronic hepatitis $\mathrm{C}$ treatment, early detection of D.M will not only reduce the cost of treatment failure but will also help in identifying the patients who require early management of type 2 diabetes mellitus.

The control of glucose abnormalities in $\mathrm{CHC}$ not only improves response to anti viral therapy but also decrease incidence of hepatocellular carcinoma.

Copyright @ 15 Dec, 2012.

\section{REFERENCES}

1. Minuk GY, Cohen AJ, Assy N, Moser M. Viral hepatitis and the surgeon. HPB (Oxford) 2005;7:56-64.

2. Asif SA, Iqbal R, Hussain $\mathrm{H}$, Khan MH. Awareness of viral hepatitis in ten villages of district. Nowshera Gomal J Med Sci 2009; 7:10-3.

3. Zakiullah M. Beware of hepatitis C - the silent epidemic. Med Today 2005; 3:26-9.

4. Strauss E. The importance of bacterial infections as precipating factors of chronic hepatic encephalopathy in cirrhosis. Hepatogastroenterology1998; 45:900-4.

5. McMahon JM, Pouget ER, Tortu S. Individual and couple-level risk factors for hepatitis C infection among heterosexual drug users: a multilevel dyadic analysis. J Infect Dis. $2007 ; 195: 1572-81$.

6. Mukhopadhyaya A. Hepatitis C in India. J Biosc 2008 ;33:465-73.

7. Ozaras R, Tahan V. Acute hepatitis C: prevention and treatment. Expert 2009;7:351-61.

8. Kamal SM. Acute hepatitis C: a systematic review. Am J Gastroenterol. 2008 ;103:1283-98.

9. Rauch A, Gaudieri S, Thio C, Bochud PY. Host genetic determinants of spontaneous hepatitis $C$ clearance. Pharmacogenomics $2009 ; 10: 1819-37$.

10. Santantonio T, Medda E, Ferrari C, Fabris P, Cariti G, Massari $\mathrm{M}$, et al. Risk factors and outcome among a large patient cohort with community-acquired acute hepatitis C in Italy. Clin Infect Dis. 2006;43:1154-9. 
11. Zafar F, Shoaib A, Umar M. Patterns of abnormal liver function tzests in viral hepatitis. Ann Pak Inst Med Sci 2006;2:260-4.

12. Tayyab G, Israrul Haque, Tanveerus Salam, Abid S, Shahid N. Adverse effect profile of patients receiving anti viral treatment for chronic Hepatitis C virus infection. Ann King Edward Med Coll 2005;11:445-6.

13. Friedman LS. Liver, billiary tract and pancreas. In: McPhee SJ, Papadakis MA, Tierney LM, editors. Current medical diagnosis \& treatment. 48th ed. New York: McGraw-Hill; 2008.p.566-604.

14. Hoyert DL, Arias E, Smith BL, Murphy SL, Kochanek KD. Deaths: final data for 1999. Natl Vital Stat Rep 2001:49:1-113.

15. Anderson RN. "Deaths: leading causes for 2000" National vital statistics reports. 2003; 50:16.

16. Hayes PC, Simpson KJ, Lorden OJ. Liver and biliary disease.In: Haslett C, Chilvers ER, Boon NA, Colledge NR. editors Davidson's principle and practice of medicine. 19th ed. Edinburgh: Churchill Livingstone; 2002: 831-8.

17. Runyon BA, Testa M. Hepatitis B and C. Am J Gastroentrol 1999; 16: 835- 40.

18. Anslo P, Brinton LA, Nyren 0 . Viral hepatitis and cirrhosis. N Engl J Med 1996; 13: 203-6.

19. Khan $H$, Zarif $M$. Risk factors, complications and prognosis of cirrhosis in a tertiary care hospital of Peshawar. Hep Mon 2006; 6: 7-10.

20. Lonardo A, Adinolfi LE, Petta S, Crax A, Loria P. Hepatitis $C$ and diabetes: the inevitable coincidence? Expert Rev Anti Infect Ther 2009:293-308.

21. Huang JF, Yu ML, Dai CY, Hsieh MY, Hwang SJ, Hsiao PJ, et al. Reappraisal of the characteristics of glucose abnormalities in patients with chronic hepatitis C infection. Am J Gastroenterol 2008; 103:1933-40.

22. Suliman MI, Imran F,Irfan S. Relationship between chronic hepatitis C and type-2 diabetes mellitus in Bhawalpurian patients. Professional Med J 2004; $11: 315-9$.

23. Chehadeh W, Abdella N, Ben-Nakhi A, Al-Arouj M, Al-
Nakib W. Risk factors for the development of diabetes mellitus in chronic hepatitis C virus genotype 4 infection. J Gastroenterol Hepatol 2008; [Epub ahead of print].

24. Moucari R, Asselah T, Cazals-Hatem D, Voitot H, Boyer $\mathrm{N}$, Ripault MP, et al. Insulin resistance in chronic hepatitis C: association with genotypes 1 and 4, serum HCV RNA level, and liver fibrosis. Gastroenterology 2008; 134:416-23.

25. Imazeki F, Yokosuka 0, Fukai K, Kanda T, Kojima H, Saisho $\mathrm{H}$. Prevalence of diabetes mellitus and insulin resistance in patients with chronic hepatitis $\mathrm{C}$ : comparison with hepatitis B virus-infected and hepatitis C virus-cleared patients. Liver Int 2008; 28:355-62.

26. Pradhan AD, Ridker PM. Do atherosclerosis and type 2 diabetes share a common inflammatory basis? Eur Heart J 2002; 23:831-4.

27. Romero-Gómez M. Insulin resistance and hepatitis $\mathbf{C}$. World J Gastroenterol. 2006;12:7075-80.

28. Veldt BJ, Chen W, Heathcote EJ, Wedemeyer H, Reichen J, Hofmann WP, et al. Increased risk of hepatocellular carcinoma among patients with hepatitis C cirrhosis and diabetes mellitus. Hepatology 2008; 47:185662.

29. Lecube A, Hernández C, Simó R, Esteban JI, Genesc J. Glucose abnormalities are an independent risk factor for nonresponse to antiviral treatment in chronic hepatitis C. Am J Gastroenterol 2007; 102:2189-95.

30. Parise ER, Oliveira AC. Insulin resistance in chronic hepatitits C. Arq Gastroenterol. 2007;44:178-84.

31. García-Compean D, Jaquez-Quintana J0, MaldonadoGarza H. Hepatogenous diabetes. Current views of an ancient problem. Ann Hepatol.2009 ;8:13-20.

32. Allison ME, Wreghitt T, Palmer CR, Alexander GJ. Evidence for a link between hepatitis $C$ virus infection and diabetes mellitus in a cirrhotic population. $J$ Hepatol 1994; $21: 1135-9$

33. Khokhar N. Association of chronic hepatitis C virus infection and diabetes mellitus. Pak $\mathrm{J}$ Med Res 2002;41:155-8. 
34. Qureshi F, Qureshi F, Anjum Q, Zuberi SJ. Is the high frequency of diabetes type 2 in chronic hepatitis C virus infection due to strong family history? J Ayub Med Coll Abottabad 2005; 17:90-1.

35. Claudia 0 Zein, Levy C, Basu A and Zein NN. Chronic Hepatitis C and Type II Diabetes Mellitus: A Prospective Cross-Sectional Study Hepatitis C and Type II Diabetes Mellitus. Am J Gastroenterol 2005;100: 48-55.

36. Alavian SM, Hajarizadeh B, Nematizadeh F, Larijani B. Prevalence and determinants of diabetes mellitus among Iranian patients with chronic liver disease. BMC Endocr Disord. 2004;4:4.
37. Lecube A, Hernández C, Genesc J, Esteban Jl, Jardí R, Simó $R$. High prevalence of glucose abnormalities in patients with hepatitis $\mathrm{C}$ virus infection: a multivariate analysis considering the liver injury. Diabetes Care 2004; 27: 1171-5.

38. Ryu JK, Lee SB, Hong SJ, Lee S. Association of chronic hepatitis $\mathbf{C}$ virus infection and diabetes mellitus in Korean patients. Korean J Intern Med. 2001; 16:18-23.

39. Wang CS, Wang ST, Yao WJ, Chang TT, Chou P. Hepatitis C virus infection and the development of type 2 diabetes in a community-based Iongitudinal study. Am J Epidemiol 2007;166: 196-203.

\section{AUTHOR(S):}

1. DR. GHAZANFAR ALI SINDHU, FCPS

Assistant Professor of Medicine

Punjab Medical College, Faisalabad.

2. DR. SADAF NAZ, MBBS

Registrar, Medical Unit-II

Allied Hospital, Faisalabad.

3. DR. FRAZ SAEED QURESHI, FCPS

Senior Registrar of Medicine

Allied Hospital, Faisalabad.

4. Dr. Zaheer Ahmed, MBBS

Registrar, Medical Unit-II

Allied Hospital, Faisalabad.
5. Dr. Tamur Islam, MBBS

House Officer, Medical Unit-II

Allied Hospital, Faisalabad.

Correspondence Address:

Dr. Ghazanfar Ali Sindhu

Medical Unit-II

Allied Hospital, Faisalabad.

trueman228@gmail.com
Article received on: 09/06/2012 Accepted for Publication: 15/12/2012 Received after proof reading: 08/02/2013

\section{PREVIOUS RELATED STUDIES}

Dilshad Muhammad, Khalid Amin, Amin Anjum, Masood Javed. CHRONIC HEPATITIS C VIRUS INFECTION; ASSOCIATION WITH TYPE 2DIABETES MELLITUS (Original) Prof Med Jour 17(4) 557-562 Oct, Nov, Dec 2010.

Khalid Amin, Israr Kafeel, Zafar alam, Muhammad Zakria, Masood Javaid. ROLE OF AMANTADINE IN TREATMENT OF CHRONIC HEPATITIS C (Original) Prof Med Jour 11(3) 253-260 Jul, Aug, Sep, 2004.

Muhammad Afzal, Irfan Ahmed Mughal, Naushen Afzal, Muhammad Badar Bashir, Fiyaz Ahmed Malik.CHRONIC HEPATITIS C INFECTION; CORRELATION OF GLUCOSE TOLERANCE TEST, THE LEVELS OF FASTING BLOOD SUGAR (FBS) AND HEMOGLOBIN (Original) Prof Med Jour 11(2) 222-227 Apr, May, Jun, 2004.

Muhammad Imran Suliman, Faiqa Imran, Shahid Irfan. RELATIONSHIP BETWEEN CHRONIC HEPATITIS C AND TYPE-2 DIABETES MELLITUS IN BHAWALPURIAN PATIENTS (Original) Prof Med Jour 11(3) 315-319 Jul, Aug, Sep, 2004.

Shaukat Ali, Syed Khurram Shahzad, Atiq ur Rehman Slehria. CHRONIC HEPATITIS C; RESPONSE TO INTERFERON AND RIBAVIRIN COMBINATION (Original) Prof Med Jour 17(4)563-567 Oct, Nov, Dec 2010. 